\title{
Integration Policy for Syrian Refugees' Access to Turkish Higher Education: Inclusive Enough?
}

\author{
Hakan Ergin and Hans de Wit
}

\section{Introduction}

Forced displacement has been a "tragic destiny" of humanity (Ergin 2016). Even the first human beings, Adam and Eve, experienced it when they ate the "forbidden fruit", according to the Jewish, Christian and Islamic religions. Since then it has repeated itself on the Earth in the forms of individual and mass movements from a place to another, such as the cases of early sophists in Ancient Greece, European tribes in the Migration Period and German Jewish scholars in Nazi Germany.

History is repeating itself at the moment, and the world is witnessing a historic case of forced displacement. As the recent statistics of the United Nations Refugee Agency (UNHCR) indicate, 37,000 people a day are forced to displace from a place to another due to persecution and conflicts in their home countries (UNHCR 2019). This number is a result of the ongoing conflicts around the world, such as the fight between the government and opposition forces in South Sudan, everlasting internal instability in Afghanistan since the U.S. intervention in 2001 and economic crisis in Venezuela.

Beyond any doubt, the global displacement crisis has become more "catastrophic" with the recent conflict in Syria which has led to "the largest displacement crisis in the world", recorded since World War II (UNHCR 2018:3). Due to this, the world has witnessed the murder of more than half a million people, internal and external displacement of over thirteen million, dead bodies of babies by the Aegean Sea, who were trying to arrive in Europe with the hope for "a better life" with their families, and endless political discussions about how to manage the huge refugee crisis until the conflict comes to an end (Ergin 2019a; Human Rights Watch 2019; Ibrahim 2018).

Much attention has been given to the challenges of developed countries in receiving refugees from developing countries, as in the Syrian case, where the refugees

\footnotetext{
H. Ergin ( $ه)$

Istanbul University, Istanbul, Turkey

e-mail: hakan.ergin1@yahoo.com

H. de Wit

Center for International Higher Education, Boston College, Chestnut Hill, USA

e-mail: dewitj@bc.edu 
who have been able to enter countries like Germany were closely followed by media reports. But it is a fact that the large majority of refugees are not only coming from the developing world, but also are hosted in the developing world, in particular neighboring countries (UNHCR 2019). The same, as a result, applies to the challenges of refugees to access higher education in these countries (Unangst et al. 2020). Developing countries are still in the process of massification with a higher demand than supply for local students, and, as a result, refugee students have more difficulty to enter higher education and face resistance from local students and communities, fearing that they take their places and decrease quality. Their harsh struggle for getting the right to higher education in developing regions mostly remains far from the center of attention.

As most forced displacement cases do, the conflict in Syria "poses an unprecedented challenge for neighboring countries" (Balsari et al. 2015: 942). Being one of the neighboring countries, Turkey has become a destination for 3.6 million Syrians, which has made it host to the largest group of refugees (UNHCR 2020). With a welcoming open-door policy, Turkey has provided the Syrian refugees with humanitarian aid, the right to education, residence and work permits (Ergin 2016). It was recently reported that government spending on the Syrians in Turkey has already exceeded USD 40 billion (Euronews 2019).

The unceasing war in Syria and long stay of the "unexpected" Syrian guests "forced" Turkish government to make academic and financial reforms to enhance their access to Turkish higher education, which is introduced as 'forced internationalization of higher education' in the literature (Ergin et al. 2019). These reforms included establishing Arabic-taught programs, providing scholarships and developing facilitative admission processes special to the Syrians in order to foster their access. The reforms enabled over 27.034 Syrians to enroll in a study program at Turkish universities as of the end of 2019 (Council of Higher Education [CoHE], 2020). This has made Turkey host to one of the largest groups of refugee students in the world (Ergin and de Wit 2019).

Turkey's long-lasting humanitarian efforts for enhancing Syrian refugees' access to higher education is undoubtedly admirable and a good model for other countries. It is promising that there is an increasing local and international research interest in this. Nevertheless, it is disappointing to state that most of the available research lacks a systemic questioning to what extent this long-lasting government policy of enhancing Syrian refugees' access to higher education in Turkey is inclusive. In this respect, taking a critical perspective, this study will examine who has been granted access to higher education and who has been left behind by this policy. Using official statistics, it will discuss the distribution of the Syrian university students in Turkey by gender, associate degree/undergraduate/graduate level, public/private university type, geographical region of the university, type of sponsoring for their higher education and higher education attainment of their parents. Following this discussion, the study will end up with recommendations for making this eight-yearold policy more inclusive, equitable and non-discriminative. 


\section{The Syrian Conflict and Its Impact on Turkey}

In 2001, a pro-democracy group started protests against Syrian President Bashar Al-Assad. The group asked him to stop his authoritarian practices and move to a more democratic regime, which they missed since 1971 when the Assad family came to power. Bashar Al-Assad regarded these demonstrations as a real threat. $\mathrm{He}$ suppressed them by military, paramilitary and police forces. The resistance of the anti-regime demonstrators increased with the extensive use of power by security forces. This led the small-scale demonstrations to turn into a civil war between the two parties (Encyclopedia Britannica 2019; Cousins 2015). However, due to external interventions of other countries, such as the U.S., Russia, Saudi Arabia, Iran and North Atlantic Treaty Organization (NATO) nations, it is considered as a real conflict, no more a civil fight between local forces (Ghaddar 2016).

However named, the conflict in Syria caused an ongoing tragedy which includes the death of over 400,000 people (Council on Foreign Relations 2019) and internal displacement of almost seven million (UNHCR 2019). More than 13 million people in Syria are now in need of humanitarian aid, and over half of the public institutions, including hospitals, have been destroyed or they function partially (UN News 2019). The conflict has not only caused chaos inside Syria but also across the region. Up to now, it has forced over 5.6 million Syrians to move to another country, mostly a neighboring one. Accepting 3.6 million Syrians, Turkey has become a host to the largest group of refugees across the world (UNHCR 2020).

It is possible to observe three stages in Turkey's integration policy for Syrian refugees. In the first stage, between 2011-15, the Turkish Government established tent cities in the south of Turkey and provided Syrian refugees with humanitarian aid. In the Temporary Protection Regulation issued in 2014, Syrians in Turkey were identified as "guests under temporary status". This reveals Turkish Government"s assumption that Syrian refugees' stay in Turkey would not be a long one. The second stage started in 2015 when the refugee influx from Turkey into Europe started. The European Union (EU) asked Turkey to make a deal in order to prevent the refugee flow into European countries. A Joint Action Plan was signed by the two parties in November 2015. Accordingly, both parties agreed on the need for more collaboration in order to prevent irregular migration. The second stage proved that European countries were not and would not be willing to share the burden of hosting Syrian refugees, and Turkey would remain to be a final or permanent destination for refugees. In the third stage beginning from 2016 and continuing up to now, the Turkish Government has been working hard to help Syrian refugees integrate into Turkey by enhancing their employment, access to education and even providing some of them with citizenship. (Erdoğan and Erdoğan 2018; Ergin 2016; Ergin and de Wit 2019; İçduygu and Şimşek 2016). 


\section{Integrating Syrian Students into Turkish Higher Education}

The stay of Syrian refugees in Turkey and the conflict in Syria lasted longer than expected. This forced the Turkish Government to meet Syrian refugees ' needs in the long run. Thus, the Council of Higher Education (CoHE), a government body which plans and coordinates higher education in Turkey, has taken an action to enhance Syrian refugees' access to universities.

In order to enhance potential Syrian students ' access to universities, CoHE has made several academic and financial reforms. The first academic reform in 2012 enabled Syrian refugees to get into seven universities in Turkey as a special student. The universities were specially chosen amongst the ones in the south of Turkey, where the refugee population was the highest. The second reform in 2013 allowed Syrian refugees with proof of former academic qualifications to apply for a program at any universities in the country. The quota for the Syrian refugees was restricted to ten per cent of that of Turkish students. The third reform in 2015 allowed eight universities to establish Arabic-taught programs (CoHE 2012, 2015; The Official Gazette 2013; Ergin and de Wit 2019).

Academic reforms for Syrian refugees ' access to universities were supported by financial reforms. In 2014, with a decision of the cabinet, Syrian university students were exempted from paying a tuition fee, which was expected to be paid by international students in Turkey. In addition, as of 2016, Syrian university students have been provided with government scholarships (Ergin and de Wit 2019; The Official Gazette 2014).

It is obvious that the Turkish Government worked hard to enhance Syrian refugees * access to higher education. Figure 1 shows the effect of this effort on the change in the number of Syrian students in Turkish higher education from the beginning of the Syrian conflict to date.

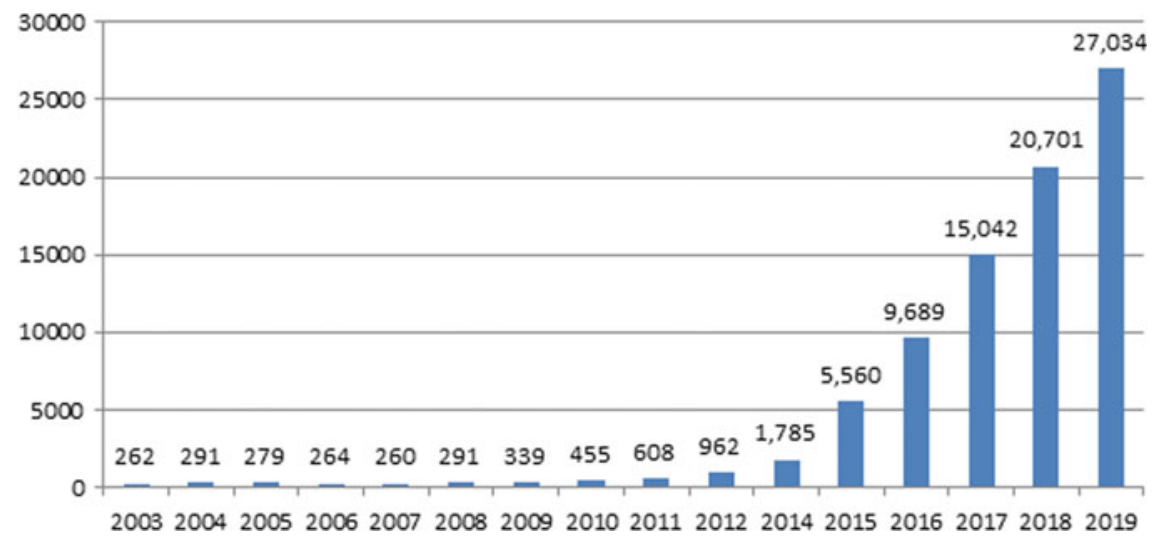

Fig. 1 Change in the Number of Syrian University Students in Turkey* Source CoHE (2020) 
As Fig. 1 illustrates, the number of Syrian university students in Turkey has increased significantly since the conflict started in 2011. Until that time, this number had not exceeded 608. It reached 5,560 in 2015, 15,042 in 2017 and reached 27,034 in 2019. This reveals that the government reforms discussed above enhanced Syrian refugees' access to universities.

\section{A Closer Look at Syrian Students in Turkish Higher Education}

Beyond any doubt, Turkey has made significant efforts and sacrifices for the sake of enhancing the Syrian refugees' access to universities in Turkey. This policy enabled a group of Syrian students to integrate into the largest higher education system in the European Higher Education Area. This rare case of forced internationalization (Ergin et al. 2019) should be sustainable and more inclusive to help more refugees access universities. Thus, it is vital to take a critical perspective to discuss its inclusivity. For this reason, a closer look at Syrian refugees who are already in the system is required.

First of all, the distribution of Syrian students at Turkish universities by genders will be presented to have a better understanding of to what extent individuals of either gender can access universities. Out of 27,034 Syrian university students in Turkey, $63 \%$ are male, and $37 \%$ are female. This shows that there is no equal distribution of them by gender, which will be discussed more in the next section.

To understand the integration policy better, revealing the distribution of Syrian students by level of study programs is noteworthy. $75 \%$ of Syrian university students in Turkey are enrolled in an undergraduate program. This is followed by the ones in associate degree, master's and doctoral degree programs at respectively 17, 6.5 and $1.5 \%$.

Currently, there are 207 universities in Turkey (CoHE 2020). 129 of them are public, and 78 are private foundation universities. The number of Syrian students in public and private universities can give us an idea about to what extent the integration policy has extended beyond both types of higher education institutions in the country. While $86.4 \%$ of Syrian students are enrolled in a public university, $13.6 \%$ of them study in a private one. This reveals that the government-led integration policy has not been adopted equally by public and private universities.

Turkey is comprised of seven geographical regions. As 240 thousand out of 3.8 million Syrian refugees only live in the government-run refugee camps, a vast majority of Syrian refugees are in urban areas in these geographical regions (UNHCR 2020). Not only the overall Syrian population unequally spreads over the country, but also Syrian university students. The highest ratio of Syrian students is in Marmara Region at $27.2 \%$, followed by South East Anatolia Region and Mediterranean Region, respectively at 25 and $14.6 \%$. In other words, $66.8 \%$ of them study in a university in either Marmara Region, the most developed part of the country, or the 
other two, which are in the south. More capacity at universities and job opportunities for the Syrians in the developed region, on the one hand, and the proximity of the southern regions to Syria, on the other hand, are the main reasons for this unbalanced distribution.

There are no available country-wide data about the financial status of Syrian students in Turkey. However, Erdoğan and Erdoğan's (2018) survey with 395 Syrian students in Turkish universities gives an idea about it. Out of them, $18 \%$ receive a scholarship, $24.93 \%$ work, and 57.65\%'s education expense is sponsored by their families. This reveals that the number of Syrian students who take a scholarship is quite low. It complies with another source which notes that the ratio of Syrian students in Turkey who take a government scholarship is $5.7 \%$ only (Mülteciler Derneği 2019).

Lastly, knowing higher education attainment of Syrian students' parents can give an idea about who can provide their children with higher education under refugee status. No nation-wide social, economic, demographic or educational data are available about Syrian university students' parents. However, findings about higher education attainment of 379 Syrian students' parents can give us a clue about the profile of parents (Erdoğan and Erdoğan 2018). A vast majority of this group of Syrian students' parents attained higher education. Accordingly, both parents of $21.37 \%$ attained higher education, only father of $30.87 \%$ and only mother of $7.65 \%$ attained it. Neither parent of $40.11 \%$, on the other hand, attained higher education.

\section{Discussion on the Inclusivity of the Policy}

As its very current definition underlines, internationalization of higher education aims to "make a meaningful contribution to society" (de Wit and Hunter 2015:3). This cannot be achieved by confining higher education to an elite club who can afford to study in another country (Ergin 2019b). By enhancing Syrian refugees ' access to universities, Turkey has made a real effort to enable untraditional international students who cannot meet traditional requirements of being an international student such as a fund, proficiency in a host country 's language and proof of previous academic credentials (Ergin et al. 2019). Nevertheless, a closer look at the above given available official statistics reveals that inclusivity in enhancing Syrian refugees ' access to higher education in Turkey has not fully been achieved yet for several aspects.

As mentioned, only $37 \%$ of Syrian students in Turkish universities are female. Compared to that of local female students, this ratio is low as almost $50 \%$ of total Turkish university students are female (CoHE 2020). This might result from societal and cultural reasons regarding women's place in Syrian society. Marriage at an early age is more common, and birth rate is higher in Syrian society than in Turkish society. To make matters worse, post-war trauma and lack of income and security might force Syrian women to marry to a local man, take care of family members at home or work in order to contribute to family budget (Barin 2015; Çakır 2017; Erdoğan et al. 2017; Hohberger 2018). 
Next, 92\% of current Syrian students in Turkish universities are enrolled in an associate or undergraduate level study program. It means that eight percent is pursuing a graduate degree only (CoHE 2020). This huge imbalance between the levels of enrollment can be caused by several reasons. Firstly, Turkish universities may not be attractive enough for Syrian refugees to pursue a graduate degree. In a survey of 360 Syrian university students in Turkey, it is noted that almost half are willing to move to a third country. Western countries, such as Canada, UK, Germany, USA and Sweden, are on the top of the most desired destinations by this group of Syrian students (Erdoğan et al. 2017). The increase in the number of Syrian students in these countries confirms this inference. For example, there is a high demand for higher education in German universities by Syrian refugees. The number of Syrian university students in Germany increased by $69 \%$ between the years $2017-18$ and reached 8,618. Of the newly registered refugees in 2018/19 winter semester, $22 \%$ are graduate students (Trines 2019). Secondly, Syrian refugee students might have difficulties to get access to graduate education by lack of documentation of their previous education and equivalencies, a rather general problem for refugees' access to higher education, but more so for graduate education.

Only $13.6 \%$ of Syrian students in Turkey are enrolled in private universities (CoHE 2020). It means that - except a few individual exceptions- Syrian students in private universities have to cover their own expenses, such as a tuition fee. This inevitably divides refugee parents into two, ones who can afford their children's study in a private university and others who cannot.

In addition to the imbalance in Syrian university students' number by type of institutions, another imbalance is observed regarding the geographical regions they are in. There are seven geographical regions in Turkey. Yet, $66.8 \%$ of Syrian students are enrolled in universities in three of these regions, Marmara, which is the most developed region with the highest number of universities, and Southeastern and Mediterranean, which are close to Syria (CoHE 2020).

Important to note here also is that very few Syrian university students in Turkey sponsor their education cost by a scholarship. According to Mülteciler Derneği (2019), this ratio does not exceed 5.7. As the above-given survey of a group of Syrian students reveals, education cost of $57 \%$ of the group is sponsored by their parents, while 25\% have to work for it (Erdoğan and Erdoğan 2018). This reminds us of the risk of elitism in internationalization (Ergin 2019b). A vast majority of today 's international students are funded by their wealthy parents. If the same applies to Syrian university students in Turkey, then we have to face a risk that only the Syrian parents in Turkey who can afford their children's study in a university or Syrian students who are healthy and fortunate enough to find a job to afford their costs are included in the system.

Last but not least, parents' awareness about the significance of higher education may play an important role in their children's access to universities. Lack of official statistics makes it unlikely to come up with a socio-economic and educational inference about parents of Syrian university students. However, as the above-given data about a group of Syrian students indicate, $60 \%$ of them have parents either or both of which have attained higher education (Erdoğan and Erdoğan 2018). This reminds us 
of the concept of family educational capital (Howard et al. 1996). If the policy mostly enhances children of parents who have higher education capital, then it means that children of others who do not have this capital are left behind.

\section{Conclusion}

It should be noted here again that hosting 3.6 million Syrian refugees and providing 27,034 of them with access to higher education (CoHE 2020; UNHCR 2020), Turkey has served as a model to other countries. This study does not expect an emerging country to include refugees in higher education flawlessly. However, in order to attain a more inclusive policy, it brings forward several recommendations:

- Special projects for encouraging more female Syrian refugees to access higher education should be planned and implemented. Scholarships open to application of female Syrians only, daycare at universities for mother refugees' kids and raising Syrian parents' awareness about their daughters' higher education attainment could be among possible practices.

- A long-term route map should be made to enhance more Syrian refugees' access to graduate programs. Job opportunities on the campus, such as a graduate assistantship, and special quotas for Syrian students in graduate program admissions could foster Syrian refugees' access.

- Private universities should be included in the policy in a more active way. Each private university should admit a certain number of Syrian refugees with a full scholarship and without expecting a tuition-fee payment.

- In order for a more balanced distribution of them around the country, regional quotas for Syrian students should be determined.

- In order not to leave the access to higher education only to those whose parents can afford it, more scholarship opportunities should be provided.

- It is obvious that Syrian parents with higher education attainment are already aware that their children should attain higher education. In order not to ignore the others whose parents do not have this educational capital, campaigns should be organized to raise awareness of Syrian parents about the significance of higher education.

Refugees face similar challenges while they struggle to access higher education in their host countries. Wherever they are, financial restrictions, family issues, postdisplacement traumatic experiences, bureaucratic problems and local tension in the host society could be counted as common barriers before their right to higher education. For this reason, the findings and recommendations of this study in our opinion are not only relevant for the case of Syrian refugee students in Turkey, but also for other countries in the Middle Eastern region and in other contexts, such as Venezuelan refugees in Latin America and refugees from Myanmar in South Asia (Unangst et al. 2020). 


\section{References}

Balsari, S., Abisaab, J., Hamill, K. \& Leaning, J. (2015). Syrian refugee crisis: When aid is not enough. The Lancet, 385(9972), pp. 942-943.

Barin, H. (2015). Türkiye'deki Suriyeli kadinlarin toplumsal bagğlamda yassadiklari sorunlar ve çözüm ünerileri. Göç Arasştırmaları Dergisi, 1(2), pp. 10-56.

CoHE. (2012). Duyurular. Retrieved from https://www.yok.gov.tr/en

CoHE. (2015). Türkiye'de bulunan Suriyeli öğrencilerin üniversitelerimizde eğitim ve öğretimlerini alabilmelerine yönelik duyuru. Retrieved from http://www.yok. gov.tr/web/guest/duyurular;jsessionid=33DF32078B0674F167422C2F4684080D?p_

p_id=101_INSTANCE_4Zc45YfE6eNh\&p_p_lifecycle=0\&p_p_state $=$ normal\&p_p_ mode=view\&p_p_col_id=column-1\&p_p_col_pos=1\&p_p_col_count=2\&_101_INSTANCE_ 4Zc45YfE6eNh_delta=10\&_101_INSTANCE_4Zc45YfE6eNh_keywords=\&_101_ INSTANCE_4Zc45YfE6eNh_advancedSearch=false\&_101_INSTANCE_4Zc45YfE6eNh_ andOperator=true\&p_r_p_564233524_resetCur=false\&cur=90.

CoHE. (2020). Yükseköğretim bilgi yönetim sistemi. Retrieved from https://istatistik.yok.gov.tr/.

Council on Foreign Relations. (2019). Global conflict tracker. Retrieved from https://www.cfr.org/ interactive/global-conflict-tracker/conflict/civil-war-syria.

Cousins, S. (2015). Syrian crisis: Health experts say more can be done. The Lancet, 385(9972), pp. 931-934.

Çakır, H. (2017). Suriyeli mülteci kadinlarin sosyokültürel değişime uyum çabalari: Yozgat örneği. ÇOMÜ International Journal of Social Sciences, 2(4), pp. 53-68.

de Wit, H., \& Hunter, F. (2015). The future of internationalization of higher education in Europe. International Higher Education, 83, pp. 2-3.

Encyclopedia Britannica. (2019). Syrian civil war. Retrieved from https://www.britannica.com/ event/Syrian-Civil-War.

Erdoğan, M. M., Erdoğan, A., Yavcan, B., Mohamad, T. H., Kavukçuer, Y., Sanci, G. (2017). Elite dialogue: Türkiye'deki Suriyeli akademisyen ve üniversite öğrencilerinin durumu, sorunları ve beklentileri araştı rması. Ankara: HUGO \& IGAM.

Erdoğan A. \& Erdoğan M.M. (2018). Access, qualifications and social dimension of Syrian refugee students in Turkish higher education. In: A. Curaj, L. Deca, R. Pricopie (Eds.), European higher education area: The impact of past and future policies, (pp. 259-276). Cham: Springer.

Ergin, H. (2016). Turkish university students' perceptions towards their Syrian classmates. Education and Science, 41, pp. 399-415.

Ergin, H. (2019a). Refugee studies are too focused on developed countries. Retrieved from https:// www.universityworldnews.com/post.php?story=20190717102317676.

Ergin, H. (2019b). Is international higher education just an elite club? Retrieved from https://www. universityworldnews.com/post.php?story=20191104073714229.

Ergin, H. \& de Wit, H. (2019). Religion, a forceful driver for forced internationalization of higher education. International Higher Education, 99, pp. 9-10.

Ergin, H., de Wit, H. \& Leask, B. (2019). Forced internationalization of higher education: An emerging phenomenon. International Higher Education, 97, pp. 9-10.

Euronews. (2019). Erdoğan: Suriye 'de güvenli bölge olmazsa, kapilari açmak zorunda kalabiliriz. Retrieved from: https://tr.euronews.com/2019/09/05/erdogan-cumhurbaskanligi-hukumetsisteminden-donus-yok-sorunlar-sistem-degil-uygulamadan.

Ghaddar, H. (2016, December 14). Stop calling the Syrian conflict a 'civil war'. It's not. The Washington Post. Retrieved from https://www.washingtonpost.com/posteverything/wp/2016/12/ 14/stop-calling-the-syrian-conflict-a-civil-war-its-not/?utm_term=.92ab05f16a6e.

Hohberger, W. (2018). Opportunities in higher education for Syrians in Turkey: The perspective of Syrian university students on the educational conditions, needs and possible solutions for improvement. Istanbul: Istanbul Policy Center. 
Howard, V. \& McLaughlin, T. F. \& Vacha, E. (1996). Educational capital: A proposed model and its relationship to academic and social behavior of students at risk. Journal of Behavioral Education, 6, pp. 135-152.

Human Rights Watch. (2019). Syria: Events of 2018. Retrieved from https://www.hrw.org/worldreport/2019/country-chapters/syria.

Ibrahim, Y. (2018). The Unsacred and the Spectacularized: Alan Kurdi and the Migrant Body. Social Media + Society, October-December, pp. 1-9.

İçduygu, A. \& Şimşek, D. (2016). Syrian refugees in Turkey: Towards integration policies. Turkish Policy Quarterly, 15(3), pp. 59-69.

Mülteciler Derneği. (2019). Suriyeli öğrencilere verilen burs ne kadar? Retrieved from https:// multeciler.org.tr/suriyeli-ogrencilere-verilen-burs-ne-kadar/.

The Official Gazette. (2013). Yükseköğretim kurumlarinda önlisans ve lisans düzeyindeki programlar arasinda geçiş, çift anadal, yan dal ile kurumlar arasi kredi transferi yapilmasi esaslarina ilişkin yönetmelikte değişiklik yapilmasina dair yönetmelik. Retrieved from http://www.resmigazete. gov.tr/eskiler/2013/09/20130921-9.htm.

The Official Gazette. (2014). 2014-15 eğitim-öğretim yilinda yükseköğretim kurumlarinda cari hizmet maiyetlerine öğrenci katkisi olarak alinacak katki paylari ve öğrenim ücretlerinin tespitine dair karar. Retrieved from http://www.resmigazete.gov.tr/eskiler/2014/09/20140927-6-1.pdf.

Trines, S. (2019). The state of refugee integration in Germany in 2019. Retrieved from https://wenr. wes.org/2019/08/the-state-of-refugee-integration-in-germa-ny-in-2019.

UN News. (2019). Syria. Retrieved from https://news.un.org/en/focus/syria.

Unangst, L., Ergin, H., Khajarian, A., DeLaquil, T. \& de Wit, H. (2020). Refugees and Higher Education: Trans-national perspectives on access, equity, and internationalization. Global Perspectives on higher Education. Rotterdam: Brill/Sense.

UNHCR. (2018). Comprehensive protection and solutions strategy: Protection thresholds and parameters for refugee return to Syria. Retrieved from https://data2.unhcr.org/en/documents/ download/63223.

UNHCR. (2019). Figures at a glance. Retrieved from https://www.unhcr.org/figures-at-a-glance. html.

UNHCR. (2020). Syria regional refugee response. Retrieved from https://data2.unhcr.org/en/ situations/syria.

Open Access This chapter is licensed under the terms of the Creative Commons Attribution 4.0 International License (http://creativecommons.org/licenses/by/4.0/), which permits use, sharing, adaptation, distribution and reproduction in any medium or format, as long as you give appropriate credit to the original author(s) and the source, provide a link to the Creative Commons license and indicate if changes were made.

The images or other third party material in this chapter are included in the chapter's Creative Commons license, unless indicated otherwise in a credit line to the material. If material is not included in the chapter's Creative Commons license and your intended use is not permitted by statutory regulation or exceeds the permitted use, you will need to obtain permission directly from the copyright holder.

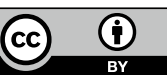

